\title{
Long-term Impact of Treated Sewage Water on Some Soil Properties and Nutrients Status in Luxor Governorate, Egypt
}

\author{
H.M. Farrag', M.A. El-Desoky ${ }^{2}$, A.A.A. Basha ${ }^{1}$ and N.M.K. Roshdi ${ }^{2}$ \\ ${ }^{1}$ Soil and Water Sci. Dept., Fac. Agric., South Valley Univ. and ${ }^{2}$ Soils \\ and Water Sci. Dept., Fac. Agric., Assuit Univ., Egypt
}

(Received : 25/ $10 / 2015$;

accepted : 17 / 4 / 2016)

RRIGATION of forests with sewage water for fuel and timber production in 1 Egypt is an approach which helps to overcome health hazards associated with sewage farming. Hopefully, sewage water will help in the expansion of the irrigated agriculture or save the fresh water for other sectors. This study was carried out to investigate the impact of irrigation with treated sewage water on the properties and nutrients status of soils in Luxor Governorate. samples of sewage water, ground water and Nile water as well as samples of soil irrigated with these water sources were collected and analyzed.

The results showed that sewage water and groundwater are considered moderately saline with an $\mathrm{EC}_{\mathrm{w}}$ of 0.88 and $1.20 \mathrm{dS} / \mathrm{m}$, respectively, while the Nile water is slightly saline $\left(\mathrm{EC}_{\mathrm{w}} 0.27 \mathrm{dS} / \mathrm{m}\right)$. With respect of their SAR, $\mathrm{RSC}$ and $\mathrm{Cl}$ values, all investigated water sources are of a high quality and can be used in the irrigation without limitations. Moreover, sewage water contained higher amount of organic matter, N, P and K compared to groundwater and Nile water.

On the other hand, most of the soils that were irrigated with sewage water were of low levels of salinity $\left(\mathrm{EC}_{\mathrm{e}}<4 \mathrm{dS} / \mathrm{m}\right)$ and sodocity $\left(\mathrm{SAR}_{\mathrm{e}}<13\right)$, indicating no threat to soil quality. Use of sewage water in irrigation also improved the chemical properties and fertility status of the soils. It increased OM, N, K and P levels in the soils while $\mathrm{pH}$ and $\mathrm{CaCO}_{3}$ values decreased. The irrigation system showed effects of treated sewage water on the soil properties. The soils irrigated with sewage water under the surface irrigation system had higher values of $\mathrm{OM}, \mathrm{EC}_{\mathrm{e}}$ total nitrogen and available phosphorus but lower $\mathrm{SAR}_{\mathrm{e}}$ and available $\mathrm{K}$ levels than those under the drip irrigation systems. Moreover, prolonged irrigated (15 years) with sewage water had a higher values of saturation percentage, organic matter, total nitrogen, available phosphorus, and available $\mathrm{K}$ but the lower ones of $\mathrm{pH}, \mathrm{SAR}_{\mathrm{e}}$ and calcium carbonate than those under the short term (4 years) use of sewage water.

Keywords: Long-term, Sewage water irrigation, Chemical soil properties, Drip irrigation; Surface irrigation

Egypt is located in the arid region, where fresh water resources are very scarce. The planners are forced to consider any source of water which might be used economically and effectively to promote further development. The reuse of agricultural drainage water and treated sewage water for beneficial purposes in Egypt is an attractive solution which hopefully may considerably help the expansion of the irrigated agriculture or save the fresh water for other sectors (Afifi et al., 2011). New projects are carried out now in Egypt aiming at expanding the green stretch in the desert by introducing forest plantations irrigated by treated sewage water, to produce timber trees of a high economic value (Salem et al., 2000). Poor water quality degrades soil quality, results in an alteration in soil physical and chemical properties and influences the soil health to a great extent. (Yerasi et al., 2013).

The irrigation with waste water of a high concentration of $\mathrm{Na}$ and $\mathrm{K}$ led to an increase in the salinity as well as the exchangeable $\mathrm{Na}$ and $\mathrm{K}$ of the irrigated soils (Khai et al., 2008). ) Narwal et al. (1993) and Rana et al. ( 2010) reported that the soil $\mathrm{pH}$ decreased by a 0.38 to one unit as a result of sewage water irrigation. Moreover, Mollahoseini (2013) indicated that the soil organic carbon 
increased with using wastewater in the irrigation from the year of 1981 to 2010 . Using wastewater in irrigation for 5060- years in soils of Calcutta (India), Friedel et al. (2000) found an increase in the soil organic carbon from 0.19 to $0.37 \%$ and from 1.24 to $1.73 \%$ after 25 years in soils of Kurukshetra (Haryana, India). In addition, longterm wastewater irrigation can be a good mean of carbon sequestration in soils and can thus be referred as a soil quality sustaining practice (Dheri et al., 2007). About $1.42 \%$ decrease in the surface soil $\mathrm{CaCO}_{3}$ content was reported with the use of waste water for irrigation purpose over the groun water intigation (McClean et al., 2003; El-Arby et al., 2006; El-Hady, 2007).

The irrigation with municipal wastewate could change soil properties role in the availability of nutrients present in the applied wastewater (Magesan et al. 1998 Mollahoseini, 2013). The wastewater irrigatio provides water, nitrogen and phosphorus as well as organic matter to the soil (Siebe, 1998 Mollahoseini, 2013). Ghafoor et al. (1999) showed that the irrigation with sewage water increased the yield of rabi crops compared to the irrigation wit well water, it also increased the total $\mathrm{N}, \mathrm{P}$ an $\mathrm{K}$ as well as the organic carbon content of soil. The sewage water can be used as alternative to fresh water irrigation and as a source of fertilizers, since it has high contents of both organic matte and nutrients (Weggler- Beaton et al., 2000). It has a high nutrient load, suspended solids an dissolved nitrates. It adds available $\mathrm{N}, \mathrm{P}$ and $\mathrm{K}$, to the soil, suggesting using sewage water as a low grade cheap fertilizer in agriculture which can markedly reduce the cost due to substitution of chemical fertilizers. (Kharche et al., 2011; Singh et al., 2012). Prolonged wastewater irrigation wa reported to produce a significant increase in the
total soil nitrogen and phosphorus (Yao et al., total soil.

This study aims to investigate the quality of treated sewage water used in the irrigation and its long term influence on some soil properties an nutrient content. The changes in soil properties

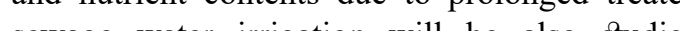
sewage wa con ina and Nile waters under forest plantation.

\section{Materials and Methods}

Study area:

This study was conducted in Luxor Governorate, that lies in the upper Egypt between Qena Governorate in the north and Aswa Governorate in the south, to and nutrient status of soils prolonged irrigate with sewage water compared to those irrigate with ground water and Nile water. Location study is considered a part of sewage water manageme station that is located southeast of Luxor city. The tudy area approximately lies between latitude of $2522.8238^{\circ}$ " to $2526.288^{\prime} 36^{\circ \prime} \mathrm{N}$ and longitude of $3236.01^{\prime} 40^{\circ \prime \prime}$ to $32^{\circ} 4305.75^{\prime \prime} \mathrm{E}$ (Figure 1).

Soil sampling and analyses:-

Four study sites were selected on the basis of differences in the irrigation system (surface and drip irrigation) and the period of irrigation (4 and 15 years). In each site, soil samples were collected from five locations. The samples were taken from each location at 3 depths $(0-30,30-$ 60 and $6090-\mathrm{cm}$ ). In addition, other soil samples were collected at the same depths from two other locations in the study area where the soils were irrigated with ground and Nile waters. Moreover, other soil samples were taken at the same depth re the soil was not eve irrigated (a virgin soil).

Particle- size distribution was carried out by the pipette method and the corresponding textural class was determined from the USDA textural class triangle. Carbonate content of the soil samples was estimated by a Collins calcimeter. The soil organic carbon content was determined according to the modified Walkely and Black method. The soil $\mathrm{pH}$ was measured by means of a digital $\mathrm{pH}$ meter in 1: 1 ratio of soil to water suspension. The extract (EC) was estimated using an electrical contract $\left(\mathrm{EC}_{\mathrm{e}}\right)$ was estimated using an electrical the soil extract were determined volumetrically by EDTA method, while sodium and potassium were measured by the flame photometer. The soil sodium adsorption ratio (SAR) was calculated using the equation: $\mathrm{SAR}_{\mathrm{e}}=$

$$
\begin{gathered}
\mathrm{Na}^{+} \\
\mathrm{Ca}^{2+}+\mathrm{Mg}^{2+}
\end{gathered}
$$

$\mathrm{Ca}^{2}+\mathrm{M}$

The available Phosphorus in the soil samples was extracted by $0.5 \mathrm{M} \mathrm{NaHCO}_{3}$ at $\mathrm{pH} 8.5$ an determined spectrophotometrically. The available potassium in the soil samples was extracted with $1 \mathrm{~N}$ ammonium acetate at $\mathrm{pH} 7.0$ and determin using the flame photometer. The total nitrogen in the soil samples was determined using the microkjeldahl method (Page et al, 1982, klute, 1986 and USDA, 1996).

Water sampling and analysis:-

Water samples were collected from the three types of water resources (sewage water, groundwater and Nile water). Parameter analysi included $\mathrm{pH}$, total soluble salts, sodium adsorptio ratio, residual sodium carbonate, soluble cation and anions, organic matter, total nitrogen, phosphorous and potassium.

The total soluble salts were determined by samples $\left(\mathrm{EC}_{\mathrm{w}}\right)$; the $\mathrm{pH}$ of the water samples was measured using a glass electrode. Carbonate and bicarbonate, chloride, calcium and magnesium ion in water samples were volumetrically determine by the titration methods. Sodium and potassiun ions were measured by flame photometer and the sulphate ions were measured using the turbidmetery method. The SAR in the water samples wa calculated as in the soll samples and the residual sodium carbonates (RSC) were calculated from the equation:

$\mathrm{RSC}=\left(\mathrm{CO}_{3}^{2-}+\mathrm{HCO}_{3}^{-}\right)-\left(\mathrm{Ca}^{2+}+\mathrm{Mg}^{2+}\right)$

The organic matter content (O.M) of the water samples were done where $250 \mathrm{ml}$ of these samples were evaporated and the organic matte was determined in the evaporates using Walkle and Black method. Other water samples of 250 $\mathrm{ml}$ were also evaporated and the evaporaters were then digested using $\mathrm{H}_{2} \mathrm{SO}_{4}$ and $\mathrm{HCLO}_{4}$ acids. In the digests, the total nitrogen was determined using the microkjeldahl method, the total phosphorus was determined calorimetrically using the chlorostanous phosphomolybdic acid method an the total porer (Page wal, 1982). photometer (Page et al, 1982).

\section{Results and Discussion}

Irrigation water quality

The characterization of the irrigation water (sewage water, groundwater and Nile water) is present in Table 1 . The $\mathrm{pH}$ value of the investigate werce water $>$ groundwater. Sewage water has a lower $\mathrm{pH}$ value compared to Nile water and ground water Its contains organic acids that may reduce the $\mathrm{pH}$ of this water (Mollahoseini, 2013). According to Pescod (1992) the $\mathrm{pH}$ of the irrigation water used in the area under study is considered within the permissible limit. The electrical conductivity $\left(\mathrm{EC}_{\mathrm{w}}\right)$ of sewage water and groundwater is 0.88 and $1.20 \mathrm{dS} / \mathrm{m}$, respectively. These two water sources are considered moderately saline, while the $\mathrm{EC}_{\mathrm{w}}$ value of the Nile water is $0.27 \mathrm{dS} / \mathrm{m}$ that is considered slightly saline, according to the guidelines of the US soil salinity laboratory (Ayers and westocot, 1985).

The sodium adsorption ratio (SAR) of al their sodicity is negligible. Therefore according to $\mathrm{EC}_{w}$ and SAR values, these water sources are of a reasonable quality that can be used for irrigation with few restrictions. Moreover, the residual sodium carbonate (RSC) values of these water sources are below $1.25 \mathrm{meq} / \mathrm{l}$ (Table 1). This means that these water sources are safe for irrigation with respect of the RSC (Eaton., 1950 and CAS, 2002).

The concentration of chlorides $(\mathrm{Cl})$ in sewage water and Nile water is less than $4 \mathrm{mmo} /$ (Table 1). According to Ayers and Westoco (1985), these water sources are considered of a good quality and they can be safely used with respect of $\mathrm{Cl}$ concentration. However, the $\mathrm{C}$ concentration in the groundwater $(5.50 \mathrm{mmol} / \mathrm{l})$ is higher than $4 \mathrm{mmol} / \mathrm{l}$, and according to Ayer and westocot (1985), its source is considere slight to moderate concerning its use in irrigation, The organic matter content of the irrigation water sources decreased in the order of sewage water $>$ groundwater $>$ Nile water. This may be due to the high amounts of organic materials in sewage water. The results in Table 1 also show that the concentration of the total nitrogen $(\mathrm{N})$, total phosphorus (P) and total Potassium (K) in the intigation water sources decreases in the order of sewage water $>$ groundwater $>$ Nile water. Sewage water contains high amounts of organic materials and potassium compounds (Afifi et al., 2011).

Long-term effect of irrigation with sewage water on some soil properties Soil texture

the soil samples had a sandy texture (78.26\%), some 
soil samples accounted by $14.5 \%$ had a loamy sand texture and few of them (7.24\%) showe sandy loam texture. However the texture of mos soil samples does not obviously change with depth.

Under the surface irrigation, all soils that were irrigated with sewage water for 4 years had sandy texture while some soils that were irrigated with this water for 15 years showed a loamy san texture, especially in the surface layers. In other wards under their conditions, the soils irrigated for 4 years recorded a higher percentage of sand an lower percentages of both silt and clay compared to those solls that were irrigated for 15 years. The same trend was found in the soils irrigated with sewage water using the drip irrigation system. The soil irrigated with ground water for 15 years still had a sandy texture while those irrigated with Nile water for that period of time showed a loamy san texture, especially in upper layers. Nile water may carry some suspended silt and clay particles to the surface layers when it is used in irrigating these soils.

Saturation percentage

The saturation percentage (SP) values of the studied soils ranged between 18.64 and $57.44 \%$ This parameter reflects the coarse texture of the studied soils (Table2) Most of the soil samples, especially those irrigated with sewage water for 4 years, had lower saturation values than those irrigated for 15 years. In general, the saturation percentage of the studied soil seems to increase with increasing the clay and silt content

Organic matter

The organic matter (O.M) content of the studied soils varied from 0.0 to $1.84 \%$ with an average value of $0.23 \%$ (Table 2). The lowest organic matter content was found in the subsurface layers of the non irrigated soil. I showed a scarcity in the plant and animal life. For the sane reason, the results also showed that the organic matter content decreased with depth. The solls prolonged irigated with sewage water resulted in increases in the soil organic matte compared to hose inigated with groundwater an Newe water helps to improve the ferlity with sewage water helps to improve the fertility statu of Khusall. The Singh (2012) and Molh hosin (2013).
Moreover, the soils irrigated with sewage water for 15 years showed a higher organic matter content than those irrigated with this water for 4 years. The irrigation system had a significan effect on the soil organic matter. Under the surface irrigation system, the soil organic matter increased more than under the drip irrigation one. This may be due to the increased amount of water that added to the soil under the surface irrigatio system that gives an opportunity to accumulate more organic matter than under the drip irrigation.

Calcium carbonate

The calcium carbonate content of the investigation soils ranged between 0.2 an $11.51 \%$ with an average value of $5.64 \%$ (Table 2). The lowest calcium carbonate content was recorded for the soil that has been irrigated by sewage water for 15 years under the surface irrigation system. On the other hand, the highe content of calcium carbonate was found in the soil that has been inigated by groundwater and in the non irrigated soil. Moreover, the results showed that, the long-term use (15 years) of sewage water in irrigation resulted more decreases in the soil calcium carbonate content compared to the shor -term use (4 years). This may be related to the decrease in the soil $\mathrm{pH}$ due to the production of organic acids as a result of the anaerobic decomposition of organic materials leading to the solublization of $\mathrm{CaCO}_{3}(\mathrm{McClean}$ et al., 2003 ,El-Arby et al., 2006). The irrigation system di not show a clear effect on the calcium carbonate content of the soils.

Soil reaction $(p H)$

The soil $\mathrm{pH}$ values of the studied area varied between 6.82 and 8.88 (Table 3). In most cases, the $\mathrm{pH}$ of the surface layers was lower than that the subsurface ones, especially for those irrigated by sewage water for long time (15 years). The results also showed that the long-term use (15 years) of sewage water in irrigation resulted in decreases in the soil reaction $(\mathrm{pH})$ more than the (hat hat, use of sewage water in irrigation showed more decrease in the soil $(\mathrm{pH})$ than using Nile water or groundwater in irrigation. The irrigation (pH). Rater et (2005) reported the the long(pH). Ratan er al. (2005) reported that he longcrops revealed a decrease in the soil $\mathrm{pH}$ by 0.4 in belo (1993) also indicated that the $\mathrm{pH}$ of the soil decreased with sewage water irrigation at all studied locations; a soil pH decrease of about one unit was observed in the soils that were irrigated by sewage water. Yao et al. (2013) showed that, the soil $\mathrm{pH}$ values of the wastewater-irrigated sites were slightly lower than those of the controlled sites at the same depths. Wastewater-irrigated soils contained higher organic carbon and nitroge contents, which could promote microorganism activity to break up organic nitrogen molecules nto inorganic nitrogen and $\mathrm{H}^{+}$. Meanwhile, wastewater itself may carry $\mathrm{H}+$ into irrigated soils too. These two aspects could result in lower pH values in wastewater-irrigated soils. Moreover, Dheri et al. (2007) indicated that the production of organic acids due to the anaerobic decomposition of organic matter was a principal cause for the reduced $\mathrm{pH}$ in the soil irrigated with waste water. Soil salinity

The electrical conductivity of the saturated soi paste extract $\left(\mathrm{EC}_{\mathrm{e}}\right)$ of the studied soils is shown in Table 3. The $\mathrm{EC}_{\mathrm{e}}$ values of the soils ranged from 0.41 to $146.70 \mathrm{dS} / \mathrm{m}$ with an average value of 5.2 $\mathrm{dS} / \mathrm{m}$. Most of the cultivated soil samples had low salinity $\left(\mathrm{EC}_{\mathrm{e}}<4 \mathrm{dS} / \mathrm{m}\right)$. In most of the sewage water irrigated soils, the surface layers showed higher $\mathrm{EC}_{\mathrm{e}}$ values than the subsurface ones due to the salt accumulation of this sewage water, El-Desoky and Gameh (1998) found that the sustained use of sewage water in irrigation caused increases in the salinity of the soils, especially in the surface layers. Roshdy (2009) indicated that the use of sewage water in ingation could result use under arid and semi-arid conditions.

The results also showed that under the surface rigation system, the long-term use ( 15 years) of sewage water in irrigation had higher $\mathrm{EC}$ values than the short-term use (4 years) of this water. O the other hand, under the drip irrigation systems, the long-term use of sewage water showed lowe $\mathrm{EC}_{\mathrm{e}}$ values than the short -term use. Moreover, the long-term use of sewage water in irrigation under vested in higher $\mathrm{EC}_{\mathrm{e}}$ values than under the drip irrigation system. The long-term use of sewage water in irrigation reduces the infiltration rate and soil porosity with less possibility of a soil structure change under the surface irrigation system more than under the drip irrigation system. This could be related to the low production of suspended materials in the drip irrigation system and thus low possibility of soil porosity clogging. However, under the surface irrigation system, the soil aggregates are dispersed and more fine particles are produced and moved to clog soil voids. This leads to a reduction in the soil porosity and infiltration rate and an increase in the salt accumulation under the surface irrigation system more than under the drip irrigation one. This result is in an agreement with that of AbediKoupai et al. (2006). On the other hand, the shor -term use of sewage water in irrigation under the drip irrigation system showed higher EC values han under the surface irrigation system. This may be due to the higher anount of water added to the soil under the surface irrigation system giving an opportunity to leach the accumulated salts more than the drip irrigation one.

The soil sodium adsorption ratio (SAR

The soil sodium adsorption ratio $\left(\mathrm{SAR}_{\mathrm{e}}\right)$ of the studied soils ranged from 0.28 to 13 with an average value of 1.53 (Table 3). Most of studied soils according to Abegunrin et al. (2013) were non alkaline (SAR <13). Most of the sewage water irrigated soils had lower $\mathrm{SAR}_{\mathrm{e}}$ values than the groundwater irrigated one. On the other hand the sewage water inigated solls showed higher $\mathrm{SAR}_{\mathrm{e}}$ values than Nile water irrigated one. In most soils under the long-term use (15 years) of sewage water in irrigation, the $\mathrm{SAR}_{\mathrm{e}}$ values of the surface soil layers were lower than those of the subsurface ones. However, in most soils under the short -term use (4 years) of sewage water, the $\mathrm{SAR}_{\mathrm{e}}$ values of the surface soil layers were higher than those of the subsurface ones. The results also showed that, in most cases, the soils under the surface irrigation system contained lower SA values than those under drip irrigation one.

Long-term effect of sewage water on some soil utrients

Table 3 shows the irrigation impact of sewage water on the total nitrogen, available phosphor and available potassium of the studied soil compared to those irrigated with Nile and groun 


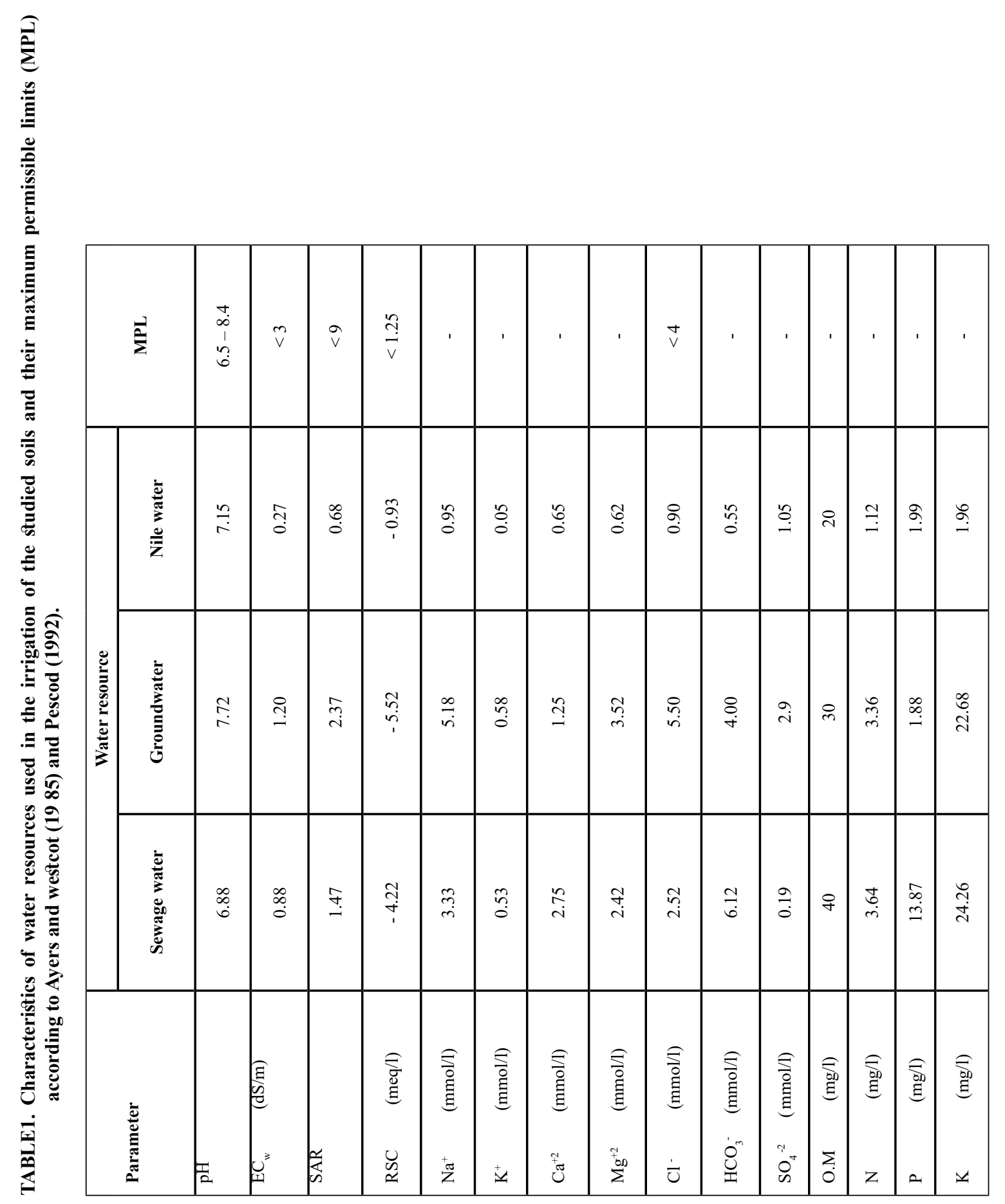

TABLE 2. Effect of water source, irrigation system, and irrigation use period on the soil texture, saturation percentage (SP), organic matter $(\mathrm{OM})$ and calcium carbonate $\left(\mathrm{CaCO}_{3}\right)$ of the studied soils

\begin{tabular}{|c|c|c|c|c|c|c|c|c|c|c|}
\hline \multirow{2}{*}{$\begin{array}{c}\text { Water } \\
\text { Source and } \\
\text { Irrigation } \\
\text { system }\end{array}$} & \multirow{2}{*}{ 范 } & \multirow{2}{*}{$\begin{array}{c}\text { ample } \\
\text { No. }\end{array}$} & \multirow{2}{*}{$\begin{array}{l}\text { Depth } \\
\text { (cm) }\end{array}$} & \multicolumn{3}{|c|}{ Particle-size distribution (\%) } & \multirow[b]{2}{*}{ Soil texture } & \multirow{2}{*}{$\begin{array}{l}\text { SP } \\
(\%)\end{array}$} & \multirow[b]{2}{*}{ ом } & \multirow[b]{2}{*}{$\mathrm{CaCO} 3$} \\
\hline & & & & Sand & Silt & clay & & & & \\
\hline \multirow{30}{*}{ 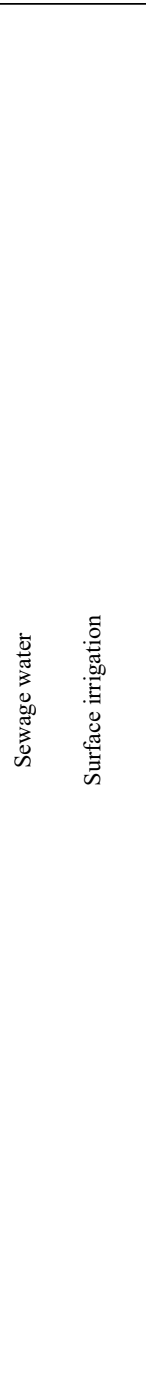 } & \multirow{15}{*}{ 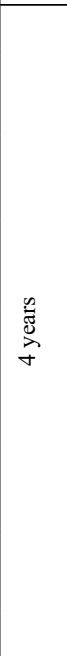 } & \multirow{3}{*}{1} & $0-30$ & 90.87 & 6.69 & 2.44 & sand & 25.67 & 0.11 & 8.96 \\
\hline & & & $30-60$ & 90.35 & 7.68 & 1.97 & sand & 25.70 & 0.10 & 8.16 \\
\hline & & & $60-90$ & 91.01 & 4.34 & 4.65 & $\begin{array}{l}\text { sand } \\
\text { sing }\end{array}$ & 23.81 & 0.03 & 8.96 \\
\hline & & \multirow{3}{*}{2} & $0-30$ & 94.36 & 2.61 & 3.04 & sand & 23.83 & 0.20 & 7.31 \\
\hline & & & $30-60$ & 93.12 & 4.39 & 2.49 & sand & 24.82 & 0.17 & 7.49 \\
\hline & & & $60-90$ & 89.94 & 5.89 & 4.18 & sand & 26.91 & 0.00 & 10.54 \\
\hline & & \multirow{3}{*}{3} & $0-30$ & 85.48 & 11.45 & 3.07 & $\begin{array}{l}\text { sand } \\
\text { sing }\end{array}$ & 25.44 & 0.20 & 8.88 \\
\hline & & & $30-60$ & 94.16 & 4.39 & 1.45 & sand & 24.50 & 0.07 & 6.41 \\
\hline & & & $60-90$ & 93.89 & 3.16 & 2.95 & sand & 28.04 & 0.01 & 5.74 \\
\hline & & \multirow{3}{*}{4} & $0-30$ & 85.48 & 11.45 & 3.07 & sand & 25.31 & 0.13 & 11.51 \\
\hline & & & $30-60$ & 91.42 & 6.13 & 2.45 & sand & 26.38 & 0.12 & 8.02 \\
\hline & & & $60-90$ & 89.76 & 7.39 & 2.86 & sand & 26.42 & 0.11 & 11.30 \\
\hline & & \multirow{3}{*}{5} & $0-30$ & 89.76 & 7.39 & 2.86 & $\begin{array}{l}\text { sand } \\
\text { s. }\end{array}$ & 27.92 & 0.34 & 10.13 \\
\hline & & & $30-60$ & 89.03 & 9.05 & 1.92 & sand & 25.67 & 0.19 & 8.92 \\
\hline & & & $60-90$ & 92.17 & 5.39 & 2.44 & sand & 25.70 & 0.01 & 8.57 \\
\hline & \multirow{15}{*}{ 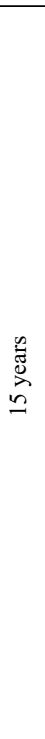 } & \multirow{3}{*}{1} & $0-30$ & 82.44 & 14.30 & 3.25 & Loamy & 33.62 & 1.84 & 4.58 \\
\hline & & & $30-60$ & 87.09 & 9.60 & 3.31 & $\begin{array}{l}\text { Sand } \\
\text { Sand }\end{array}$ & 23.35 & 0.06 & 5.73 \\
\hline & & & $60-90$ & 87.06 & 9.19 & 3.76 & Sand & 22.86 & 0.00 & 5.06 \\
\hline & & \multirow{3}{*}{2} & $0-30$ & 88.42 & 1.89 & 9.69 & Loamy & 26.80 & 0.62 & 0.20 \\
\hline & & & $30-60$ & 95.37 & 1.22 & 3.42 & sand & 23.19 & 0.03 & 6.16 \\
\hline & & & $60-90$ & 81.25 & 11.80 & 6.95 & Loamy & 20.72 & 0.07 & 6.68 \\
\hline & & \multirow{3}{*}{3} & $0-30$ & 88.82 & 5.47 & 5.71 & Sand & 29.72 & 0.81 & 4.84 \\
\hline & & & $30-60$ & 90.36 & 6.10 & 3.55 & Sand & 20.05 & 0.10 & 5.12 \\
\hline & & & $60-90$ & 94.51 & 1.66 & 3.84 & sand & 19.29 & 0.10 & 5.57 \\
\hline & & \multirow{3}{*}{4} & $0-30$ & 91.60 & 4.86 & 3.54 & Sand & 27.01 & 0.94 & 2.18 \\
\hline & & & $30-60$ & 94.61 & 3.96 & 1.42 & Sand & 25.03 & 0.26 & 5.58 \\
\hline & & & $60-90$ & 90.60 & 5.09 & 4.32 & sand & 23.37 & 0.10 & 6.38 \\
\hline & & & $0-30$ & 89.51 & 6.88 & 3.61 & Sand & 33.47 & 1.14 & 2.15 \\
\hline & & 5 & $30-60$ & 94.61 & 3.96 & 1.42 & Sand & 25.22 & 0.10 & 5.85 \\
\hline & & & $60-90$ & 92.19 & 7.60 & 0.22 & sand & 26.91 & 0.14 & 5.84 \\
\hline & & & $0-30$ & 93.97 & 3.03 & 3.00 & sand & 24.89 & 0.16 & 6.52 \\
\hline & & 1 & $30-60$ & 92.06 & 4.46 & 3.48 & sand & 22.60 & 0.04 & 5.36 \\
\hline & & & $60-90$ & 94.88 & 1.88 & 3.24 & sand & 21.64 & 0.05 & 5.97 \\
\hline & & & $0-30$ & 95.00 & 2.98 & 2.03 & sand & 22.52 & 0.14 & 5.37 \\
\hline & & 2 & & 92.57 & 4.34 & 3.09 & sand & \begin{tabular}{|l|}
25.37 \\
1.34
\end{tabular} & 0.04 & 6.24 \\
\hline & & & $60-90$ & 91.78 & 7.51 & 0.71 & sand & 18.64 & 0.04 & 3.98 \\
\hline 吾言离 & 爵 & & $0-30$ & 54.10 & 42.76 & 3.14 & sand & 23.19 & 0.16 & 5.62 \\
\hline 噌 & $\stackrel{8}{\sigma}$ & 3 & $30-60$ & 93.95 & 4.06 & 1.99 & sand & 21.57 & 0.08 & 4.96 \\
\hline & & & $60-90$ & 91.58 & 5.35 & 3.07 & sand & 22.10 & 0.10 & 7.15 \\
\hline & & & $0-30$ & 91.96 & 4.25 & 3.80 & sand & 20.28 & 0.04 & 5.77 \\
\hline & & 4 & $\frac{30-60}{60-90}$ & $\frac{92.88}{94.78}$ & $\begin{array}{l}4.13 \\
2.229\end{array}$ & $\begin{array}{l}2.98 \\
2.98\end{array}$ & $\begin{array}{l}\text { sand } \\
\text { sand }\end{array}$ & $\frac{22.84}{20.27}$ & 0.06 & $\frac{5.29}{5.71}$ \\
\hline & & & $\frac{60-90}{0-30}$ & 94.76 & $\frac{2.29}{2.98}$ & $\begin{array}{r}2.95 \\
2.03\end{array}$ & $\begin{array}{l}\text { sand } \\
\text { sand }\end{array}$ & $\frac{20.27}{21.69}$ & 0.011 & $\frac{5.71}{5.52}$ \\
\hline & & 5 & $30-60$ & 94.51 & 2.56 & 2.93 & sand & 20.83 & 0.00 & 5.26 \\
\hline
\end{tabular}




\begin{tabular}{|c|c|c|c|c|c|c|c|c|c|c|}
\hline \multirow{2}{*}{$\begin{array}{c}\text { Water } \\
\text { Source and } \\
\text { Irrigation } \\
\text { System }\end{array}$} & \multirow[t]{2}{*}{ Period } & \multirow{2}{*}{$\begin{array}{c}\text { ample } \\
\text { No. }\end{array}$} & \multirow{2}{*}{$\begin{array}{l}\text { Depth } \\
(\mathrm{cm})\end{array}$} & \multicolumn{3}{|c|}{ Particle-size distribution (\%) } & \multirow[b]{2}{*}{ Soil texture } & \multirow{2}{*}{$\begin{array}{l}\text { SP } \\
(\%)\end{array}$} & \multirow{2}{*}{$\begin{array}{l}\text { OM } \\
(\%)\end{array}$} & \multirow{2}{*}{$\begin{array}{l}\mathrm{CaCO3} \\
(\%)\end{array}$} \\
\hline & & & & Sand & Silt & clay & & & & \\
\hline \multirow{15}{*}{ 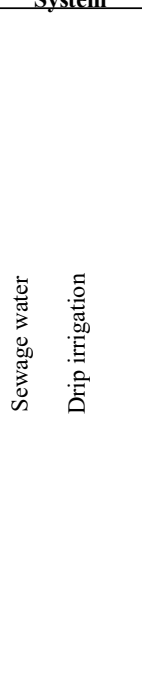 } & \multirow{15}{*}{ 商 } & & $0-30$ & 88.19 & 7.55 & 4.26 & Sand & 22.41 & 1.03 & 6.00 \\
\hline & & & $30-60$ & 87.12 & 10.69 & 2.19 & Sand & 20.08 & 0.21 & 8.02 \\
\hline & & & $60-90$ & 86.44 & 12.14 & 1.42 & sand & 22.13 & 0.01 & 7.94 \\
\hline & & & $0-30$ & 77.82 & 18.93 & 3.26 & $\begin{array}{l}\text { Loamy } \\
\text { samd }\end{array}$ & 24.41 & 0.51 & 2.43 \\
\hline & & & $30-60$ & 94.25 & 3.63 & 2.12 & sand & 23.06 & 0.11 & 0.20 \\
\hline & & & $60-90$ & 72.54 & 16.65 & 10.81 & Sandy loam & 40.39 & 0.06 & 1.26 \\
\hline & & & $0-30$ & 77.83 & 18.94 & 3.27 & $\begin{array}{l}\text { Loamy } \\
\text { sand }\end{array}$ & 24.69 & 0.32 & 4.90 \\
\hline & & & $30-60$ & 77.17 & 17.81 & 5.02 & $\begin{array}{c}\text { Loamy } \\
\text { Lomb } \\
\text { sand }\end{array}$ & 43.90 & 0.17 & 1.60 \\
\hline & & & $60-90$ & 80.32 & 16.75 & 2.94 & $\begin{array}{l}\text { Laminy } \\
\text { coand } \\
\text { sand }\end{array}$ & 39.71 & 0.06 & 0.67 \\
\hline & & & $0-30$ & 87.80 & 8.35 & 3.86 & Sand & 26.93 & 0.82 & 4.19 \\
\hline & & & $30-60$ & 72.36 & 24.05 & 3.59 & Sandy loam & 50.25 & 0.08 & 2.17 \\
\hline & & & $60-90$ & 71.71 & 25.69 & 2.60 & Sandy loam & 43.82 & 0.01 & 1.23 \\
\hline & & & $0-30$ & 87.58 & 8.06 & 4.36 & Sand & 29.19 & 0.78 & 4.49 \\
\hline & & & $30-60$ & 65.47 & 31.42 & 3.12 & Sandy loam & 54.08 & 0.10 & 1.39 \\
\hline & & & $60-90$ & 65.04 & 31.68 & 3.28 & Sandy loam & 57.44 & 0.06 & 0.61 \\
\hline \multirow{3}{*}{\multicolumn{2}{|c|}{$\begin{array}{c}\text { Groundwater Surface } \\
\text { irrigation }\end{array}$}} & \multirow{3}{*}{$\begin{array}{c}15 \\
\text { years }\end{array}$} & $0-30$ & 87.24 & 11.01 & 1.75 & sand & 21.57 & 0.48 & 4.89 \\
\hline & & & $30-60$ & 89.85 & 7.40 & 2.76 & sand & 33.98 & 0.08 & 9.66 \\
\hline & & & $60-90$ & 87.39 & 11.77 & 0.84 & sand & 36.98 & 0.07 & 10.70 \\
\hline \multirow{3}{*}{\multicolumn{2}{|c|}{$\begin{array}{c}\text { Nile water } \\
\text { surface irrigation }\end{array}$}} & \multirow{3}{*}{$\begin{array}{c}15 \\
\text { years }\end{array}$} & $0-30$ & 84.60 & 9.35 & 6.05 & $\begin{array}{l}\text { Loamy } \\
\text { sand }\end{array}$ & 21.44 & 0.22 & 0.75 \\
\hline & & & $30-60$ & 84.22 & 7.95 & 7.84 & $\begin{array}{l}\text { Loamy } \\
\text { sand }\end{array}$ & 23.34 & 0.11 & 1.81 \\
\hline & & & $60-90$ & 90.30 & 2.94 & 6.76 & $\begin{array}{l}\text { sang } \\
\text { sand }\end{array}$ & 23.17 & 0.16 & 5.23 \\
\hline \multirow{3}{*}{\multicolumn{3}{|c|}{ Non irrigated soil }} & $0-30$ & 94.95 & 1.03 & 4.02 & sand & 22.73 & 0.04 & 8.19 \\
\hline & & & $30-60$ & 82.21 & 14.42 & 3.37 & $\begin{array}{l}\text { Loamy } \\
\text { sand }\end{array}$ & 24.31 & 0.03 & 7.25 \\
\hline & & & $60-90$ & 93.67 & 2.30 & 4.03 & sand & 23.24 & 0.12 & 7.51 \\
\hline
\end{tabular}

TABLE 3. Effect of water source, irrigation system, and irrigation use period on the $(\mathbf{p H})$, salinity $\left(\mathrm{EC}_{\mathrm{C}}\right)$, sodium adsorption ratio (SARe, total nitrogen $(\mathrm{N})$, available phosphorus $(\mathbf{P})$ and available potassium $(\mathrm{K})$ of the studied sol

\begin{tabular}{|c|c|c|c|c|c|c|c|c|c|}
\hline $\begin{array}{c}\text { Water Source } \\
\text { and Irrigation } \\
\text { System }\end{array}$ & 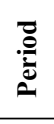 & $\begin{array}{l}\text { Sample } \\
\text { No. }\end{array}$ & $\begin{array}{l}\text { Depth } \\
\text { (cm) }\end{array}$ & $\mathrm{pH} \mathrm{(1:1)}$ & $\mathrm{EC}_{c}(\mathrm{dS} / \mathrm{m})$ & SAR & $\mathrm{N}(\mathrm{mg} / \mathrm{kg})$ & $\mathbf{P}(\mathrm{mg} / \mathrm{kg})$ & $\mathrm{K}(\mathrm{mg} / \mathrm{kg})$ \\
\hline \multirow{29}{*}{ 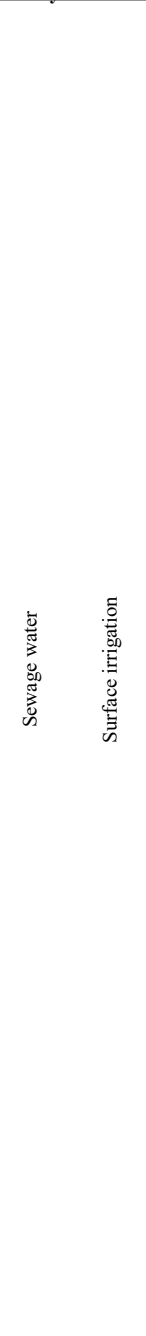 } & \multirow{15}{*}{$\frac{\sqrt[3]{y}}{8}$} & \multirow{3}{*}{1} & $0-30$ & 7.68 & 1.48 & 1.03 & 36.44 & 36.58 & 165.89 \\
\hline & & & $30-60$ & 7.66 & 1.28 & 0.28 & 31.54 & 42.51 & 217.62 \\
\hline & & & $60-90$ & 8.27 & 1.73 & 0.34 & 30.56 & 23.60 & 155.61 \\
\hline & & \multirow{3}{*}{2} & $0-30$ & 8.10 & 1.24 & 0.54 & 62.63 & 21.54 & $\begin{array}{l}156.38 \\
\end{array}$ \\
\hline & & & $30-60$ & 8.46 & 0.66 & 0.50 & 55.26 & 92.70 & 227.10 \\
\hline & & & $60-90$ & 8.19 & 0.59 & 0.44 & 31.56 & 163.48 & 175.93 \\
\hline & & \multirow{3}{*}{3} & $0-30$ & 7.55 & 0.90 & 0.99 & 63.41 & 36.70 & 165.50 \\
\hline & & & $30-60$ & 7.95 & 2.19 & 1.64 & 22.20 & 23.41 & 135.32 \\
\hline & & & $60-90$ & 8.19 & 1.23 & 1.15 & 18.56 & 22.60 & 115.06 \\
\hline & & \multirow{3}{*}{4} & $0-30$ & 7.70 & 2.53 & 1.94 & 39.96 & 36.58 & 335.51 \\
\hline & & & $30-60$ & 7.94 & 1.40 & 0.69 & 35.42 & 65.92 & 1344.99 \\
\hline & & & $60-90$ & 7.87 & 1.52 & 0.71 & 36.56 & 70.41 & 207.46 \\
\hline & & \multirow{3}{*}{5} & $0-30$ & 8.05 & 1.58 & 0.39 & 108.02 & 51.50 & 297.55 \\
\hline & & & $30-60$ & 7.96 & 0.76 & 0.89 & 59.47 & 10.86 & 156.66 \\
\hline & & & $60-90$ & 8.19 & 0.77 & 0.89 & 36.46 & 8.86 & 126.03 \\
\hline & \multirow{14}{*}{ 耪 } & \multirow[b]{2}{*}{1} & $0-30$ & 7.45 & 3.44 & 0.61 & 156.87 & 108.43 & 489.58 \\
\hline & & & $\begin{array}{l}30-60 \\
60-90\end{array}$ & 8.33 & 0.71 & $\frac{1.15}{0.03}$ & $\begin{array}{l}70.34 \\
3.3 .1\end{array}$ & $\frac{70.70}{824}$ & $\frac{328.52}{23610}$ \\
\hline & & \multirow{3}{*}{2} & $0-30$ & 7.15 & 1.44 & 0.52 & 198.21 & 96.44 & 166.11 \\
\hline & & & $30-60$ & 8.12 & 0.98 & 0.81 & 69.81 & 32.21 & 365.48 \\
\hline & & & $60-90$ & 7.86 & 0.56 & 0.65 & 33.11 & 35.21 & 358.64 \\
\hline & & \multirow{3}{*}{3} & $0-30$ & 7.37 & 0.82 & 0.29 & 128.94 & 27.72 & 245.94 \\
\hline & & & $30-60$ & 7.86 & 1.76 & 0.57 & 81.93 & 24.16 & 146.50 \\
\hline & & & $60-90$ & 7.65 & 1.39 & 0.51 & 33.11 & 42.51 & 144.97 \\
\hline & & \multirow{3}{*}{4} & $0-30$ & 7.39 & 3.42 & 1.05 & 157.50 & 72.10 & 267.65 \\
\hline & & & $30-60$ & 7.89 & 1.84 & 0.85 & 69.81 & 131.84 & 176.62 \\
\hline & & & $60-90$ & 8.12 & 1.76 & 0.86 & 25.57 & 79.78 & 173.99 \\
\hline & & \multirow{3}{*}{5} & $0-30$ & 6.82 & 3.37 & 0.76 & 156.60 & 29.42 & 196.05 \\
\hline & & & $30-60$ & 8.18 & 1.71 & 0.89 & 32.47 & 31.65 & 64.97 \\
\hline & & & $60-90$ & 7.59 & 2.56 & 1.05 & 44.25 & 40.82 & 133.51 \\
\hline \multirow{15}{*}{ 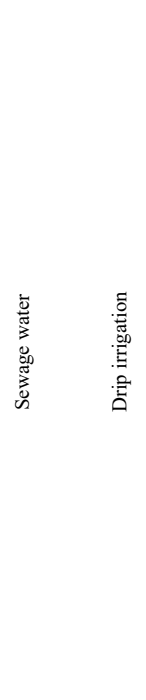 } & \multirow{15}{*}{ 产 } & \multirow{3}{*}{1} & $0-30$ & 7.79 & 2.04 & 0.53 & 50.64 & 53.52 & 264.91 \\
\hline & & & $30-60$ & 8.32 & $\begin{array}{ll}0.61 \\
\end{array}$ & 0.94 & 13.54 & 20.04 & 144.08 \\
\hline & & & $60-90$ & 7.99 & 0.68 & 1.01 & 14.53 & 11.24 & 166.24 \\
\hline & & & $0-30$ & 7.63 & 3.94 & 1.47 & 45.74 & 47.00 & 237.89 \\
\hline & & 2 & $30-60$ & 8.23 & 0.78 & 0.56 & 13.75 & 20.04 & 124.76 \\
\hline & & & $60-90$ & 8.50 & 0.88 & 0.70 & 14.03 & 37.76 & 185.58 \\
\hline & & & $0-30$ & 7.37 & 10.49 & 5.15 & 50.05 & 29.03 & 257.49 \\
\hline & & 3 & $30-60$ & 8.22 & 0.88 & 1.64 & 25.56 & 21.04 & 94.56 \\
\hline & & & $60-90$ & 8.21 & 1.35 & 2.00 & 30.51 & 38.76 & 104.86 \\
\hline & & & $0-30$ & 7.53 & 15.56 & 4.61 & 14.13 & 28.09 & 325.92 \\
\hline & & 4 & $30-60$ & 8.27 & 1.93 & 1.18 & 15.77 & 29.78 & 93.34 \\
\hline & & & $60-90$ & 8.19 & 1.53 & 1.111 & 11.42 & 11.24 & 95.36 \\
\hline & & & $0-30$ & 7.86 & 7.78 & 1.11 & 20.82 & 46.44 & 267.35 \\
\hline & & 5 & $30-60$ & 7.82 & 1.40 & 1.48 & 14.13 & 72.66 & 54.51 \\
\hline & & & $60-90$ & 7.79 & 2.04 & 1.09 & 12.93 & 39.76 & 135.10 \\
\hline
\end{tabular}




\begin{tabular}{|c|c|c|c|c|c|c|c|c|c|}
\hline $\begin{array}{l}\text { Water Source and } \\
\text { Irrigation System }\end{array}$ & 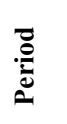 & $\begin{array}{c}\text { Sample } \\
\text { No. }\end{array}$ & $\begin{array}{l}\text { Depth } \\
\text { (cm) }\end{array}$ & $\mathrm{pH}(1: 1)$ & $\mathrm{EC}_{c}(\mathrm{~d} / \mathrm{m} / \mathrm{m})$ & $\mathrm{SAR}_{\mathrm{e}}$ & $\mathrm{N}(\mathrm{mg} / \mathrm{kg})$ & $\mathrm{P}(\mathrm{mg} / \mathrm{kg})$ & $\mathrm{K}(\mathrm{mg} / \mathrm{kg})$ \\
\hline \multirow{15}{*}{ 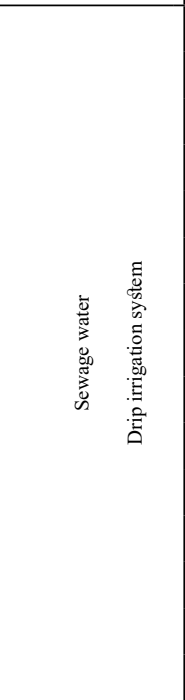 } & \multirow{15}{*}{ 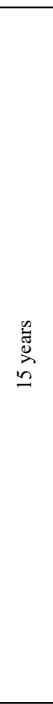 } & \multirow{3}{*}{1} & $0-30$ & 7.86 & 2.11 & 0.67 & 144.67 & 79.78 & 327.09 \\
\hline & & & $30-60$ & 8.05 & 1.03 & 0.57 & 65.51 & 35.77 & 227.05 \\
\hline & & & $60-90$ & 8.07 & 0.73 & 0.45 & 10.96 & 15.02 & 224.70 \\
\hline & & \multirow{3}{*}{2} & $0-30$ & 7.45 & 1.41 & 1.04 & 58.68 & 93.07 & 328.78 \\
\hline & & & $30-60$ & 8.18 & 1.29 & 3.28 & 33.55 & 82.02 & 205.98 \\
\hline & & & $60-90$ & 7.40 & 2.33 & 3.36 & 18.90 & 93.26 & 522.97 \\
\hline & & \multirow{3}{*}{3} & $0-30$ & 8.02 & 1.40 & 1.03 & 101.14 & 50.56 & 268.47 \\
\hline & & & $30-60$ & 8.10 & 0.65 & 1.68 & 52.73 & 43.26 & 639.59 \\
\hline & & & $60-90$ & 7.77 & 0.68 & 1.83 & 19.63 & 16.12 & 488.80 \\
\hline & & \multirow{3}{*}{4} & $0-30$ & 7.52 & 1.90 & 0.85 & 64.64 & 55.84 & 358.56 \\
\hline & & & $30-60$ & 7.75 & 0.77 & 1.28 & 26.05 & 35.06 & 674.48 \\
\hline & & & $60-90$ & 7.69 & 0.54 & 1.14 & 10.96 & 15.12 & 525.74 \\
\hline & & \multirow{3}{*}{5} & $0-30$ & 7.35 & 4.25 & 2.08 & 107.23 & 55.81 & 377.76 \\
\hline & & & $30-60$ & 7.24 & 7.70 & 2.82 & 31.43 & 14.23 & 661.73 \\
\hline & & & $60-90$ & 7.09 & 0.65 & 0.80 & 18.94 & 36.52 & 632.27 \\
\hline \multirow{3}{*}{\multicolumn{2}{|c|}{$\begin{array}{l}\text { Groundwater } \\
\text { Surface iririgation }\end{array}$}} & \multirow{3}{*}{15 years } & $0-30$ & 8.42 & 3.35 & 3.07 & 70.48 & 29.59 & 309.74 \\
\hline & & & $30-60$ & 8.88 & 2.30 & 2.02 & 78.31 & 57.87 & 187.07 \\
\hline & & & $60-90$ & 8.81 & 2.32 & 1.95 & 22.26 & 37.45 & 216.94 \\
\hline \multirow{3}{*}{\multicolumn{2}{|c|}{$\begin{array}{l}\text { Nile water } \\
\text { surface irrigation }\end{array}$}} & \multirow{3}{*}{15 years } & $0-30$ & 7.82 & 0.47 & 0.47 & 69.52 & 23.78 & 429.13 \\
\hline & & & $30-60$ & 8.06 & 0.75 & 0.51 & 59.02 & 53.37 & 512.25 \\
\hline & & & $60-90$ & 8.16 & 0.41 & 0.37 & 50.68 & 19.66 & 24.32 \\
\hline \multirow{3}{*}{\multicolumn{3}{|c|}{ Non irirgated soil }} & $0-30$ & 8.08 & 15.81 & 4.73 & 0.00 & 0.00 & 672.11 \\
\hline & & & $30-60$ & 7.67 & 63.50 & 8.37 & 0.00 & 0.00 & 337.44 \\
\hline & & & $60-90$ & 7.46 & 146.70 & 13.01 & 0.00 & 12.55 & 337.71 \\
\hline
\end{tabular}

Total Nitrogen

The total nitrogen in the studied soils varied from 0.0 to $198.21 \mathrm{mg} / \mathrm{kg}$ with an average value of $50.98 \mathrm{mg} / \mathrm{kg}$ (Table 3). Generally, increases in the total $\mathrm{N}$ of all studied soils occurred as a result of the irrigation with sewage water compare to the non irrigated soil. The soils prolonged Irrigated (15 years) with sewage water under the surface irrigation system showed highe values of the total nitrogen than those irrigated with Nile water or groundwater . Hussain et al. (2002) found that the sewage water containe organic and inorganic compounds that included nutrients like nitrogen. Afifi et al. (2011) revealed that the use of sewage water in irrigation led to an increase in the total nitrogen contents of the soil after harvesting. This may be due to the high concentration of nitrogen in the sewage water. The irrigation system had an effect on the tota nitrogen contents of the soil. In most cases, the higher values of the total nitrogen than the soils under the drip irrigation system. This may be Egypt. J. Soil Sci. 57, No. 1 ( 2017 ) attributed to the increased amount of water adde to the soils under the surface irrigation system that gives an opportunity to accumulate more organic matter and inorganic compounds including nutrients like nitrogen $(\mathrm{N})$ than under the drip irrigation system. In most cases, the total nitrogen of the soils prolonged (15 years) irrigated with sewage water were higher than those irrigated with sewage water for a short period (4 years). The results also showed that, in most soil samples, the total nitrogen decreased with depth.

Available phosphorus

The available phosphorus of the studied soils ranged from 0.0 to $131.34 \mathrm{mg} / \mathrm{kg}$ with an avera value of $42.51 \mathrm{mg} / \mathrm{kg}$ (Table 3). In genera, increases in the available phosphorus of a studied soils irrigated with sewage water occurre soils irrigated with sewage water for a long time (15 years) under the surface irrigation syste had higher available phosphorus values th those irrigated with Nile water or groundwater. compared to those of the non irrigated soil. The
In most cases, the available phosphorus values of the soils under the long-term (15 years) irrigatio with sewage water were higher than those under the short term use (4 years) of sewage water. ElKhateeb et al. (2012) indicated that the available phosphorus of the forest soils clearly increased a a result of the irrigation with sewage water; their results varied due to the period of irrigation. Use of domestic wastewater in irrigation can provides essential nutrients to the crops and improves the fertility level of soils (Ladwani et al., 2012).

In addition, Kharche et al. ( 2011) and Sing et al. (2012) found that the sewage inigated soil recorded high available $\mathrm{P}$ levels indicating their significant additions through sewage water as low grade cheap fertilizers. Moreover in mos cases, the soils under the surface irrigation system showed higher available phosphorus contents than those under the drip inrigation system. The increased amount of sewage water added to the soil under the surface irrigation system give an opportunity for organic matter and inorganic compounds that include nutrients like phosphoru to accumulate more than under the drip irrigatio system.

Available potassium

The available potassium in the studie soils ranged from 24.32 to $674.48 \mathrm{mg} / \mathrm{kg}$ wit an average value of $271.35 \mathrm{mg} / \mathrm{kg}$ (Table 3). Generally, the available potassium in mos studied soils increased as a result of the long-tern irrigation with sewage water, especially in the surface soil layers compared to that in the soils irrigated with Nile water or groundwater. The soils prolonged ( 15 years) irrigated with sewage water contained higher available potassium values than those irrigated with sewage water for a shor period (4 years). Ghafoor (1999) reported that the irrigation with sewage water increased the total potassium and the yield of rabi crops compared to the irrigation with well water. Saffari and Saffar (2013) also indicated that the irrigation with waste addition, the long-term use of sewage water

in irrigation under the drip irrigation system howed higher soil available potassium value than its use under the surface irrigation system This may be attributed to the increased amounts of water added to the soils under the surface ion system that cause the potassium to from the surface layers to the subsurface ones.

\section{Conclusions}

The present research was done in order to study the effects of the treated sew age some soil chemical properties. On the basis of currently available data, the soil salinity leve remained nomal and the sodium level indicated by the soil sodium adsorption ratio (SAR) wa below the critical level of 13 , indicating threat to the soil quality. Hence the soils could be suitable for crop production. The irrigation with sewage water also improved the chemic properties and fertility status of the studied soils. It increased levels of $\mathrm{OM}, \mathrm{N}, \mathrm{K}$, and $\mathrm{P}$ in the soils while it decreased the $\mathrm{pH}$ and $\mathrm{CaCO}_{3}$ of the soils. The use of sewage water for irrigating crops has nutritional benefits in using a water resource tha would otherwise be discarded. Sewage water irrigation also reduces the use of other water sources espeasally fresh water that can be used elsewhere such as for drinking. Other factors have to be considered and studied with using sewage water in irrigation including the presence of pathogens and chemical contaminants as well as salinity impacts on the soil structure. These can be controlled through sewage water treatment and effective farm management practices. Future research and development must focus on the use of wastewater in agriculture because fresh water sources for agriculture are diminishing while the amounts of wastewater from cities are rapidly increasing due to rapid population explosions and industrialization.

References

bedi-Koupai, J., Mostafazadeh-Fard, B. Afyun M. and Bagheri, M.R. (2006) Effect of treate in an arid region. Plant Soil Environ, 52, (8), 335344

Abegunrin, T. P., Awe,G. O., Idowu, D. O. nigbogi, O. O.O and Onofua,O. E. (2013) Effect of kitchen wastewater irigation on soil properties and growh Manage.4 (7), pp. 139145

Afifi, A. A., Abd El-Rheem,Kh.M. and Youssef,R. (2011) Influence of Sewage Water Reuse Application on Soll and the Distribution of Heavy Metals Nature and Science 9 (4), 8288- http:/

Ayers, R.S. and Westcot,D.W. (1985) Water quality for agriculture. FAO, Rome, Italy.

Egypt. J. Soil Sci. 57, No. 1 ( 2017 ) 
CAS (College of agricultural sciences) (2002) Irrigation water quality. The Pennsylvania State University, USA

Dheri, G.S., Brar, M.S. and Malhi, S.S. (2007) Heavymetal concentration of sewage-contaminated water and its impact on underground water, soil and crop
plants in Alluvial soils of Northwestern India., Communication in Soil Sci. \& Plant Anal 38, 13531370.

El-Arby, A. M. and Elbordiny, M.M. (2006) Impac of reused wastewater for irrigation on availability of heavy metals in sandy soils and their uptake by
plants. J. Applied Sci. Res, 2, 106111-

El-Desoky, M.A. and Gameh, M.A. (1998) Heavy metals mobility and changes in properties of sandy soils irrigated with untreated sewage waters at
Assiut. J. Agric. Sci. Mansoura Univ., 23 (10),
4705771947054719-

El-Hady, B.A.A. (2007) Compare the effect of polluted and river Nile irrigation water on contents of \& Biol., 3, 287294-.

El-Khateeb, M.A., Arafa, A.M., Abd El-Dayem, A.M. and Watfa, R.A. (2012) Effect of Sewage Water Irrigation on Macro Nutrients, Heavy Metals and Frequency Percentage of Fungi in Soil Cultivat with Wody Thes. Journal of 177185-, ISSN 20792158-

Friedel, J.K., Langer, T., Siebe, C. and Stahr, K. (2000) Effects of long-term waste water on soil organic matter and microbial biomass and its activities in central Mexico, Biology and Fertility of Soils, 31 (2000), 414421

Ghafoor, A., Ahmed, S., Qadir, M., Hussain, S.I. and Murtaz, G. (1999) Formation and leaching of lead
species from a sandy loam alluvial soil as related to $\mathrm{pH}$ and $\mathrm{Cl}: \mathrm{SO} 4$ ratio of leachates. J. Agric. Res. 30, 391-401.

Hussain, I., Raschid, L. Hanjra, M.A., Marikar, F. and van der Hoek, W. (2002) Wastewater Use in Agriculture: Review of Impacts and ethodological Internatiol Water Colombo, Sri Lanka.

Khai, G. P. Th., Tuan, M., Vinh, N.C. and Oborn, I. (2008) Effects of using wastewater as nutrient sources on soil chemical properties in peri - urban agricultural systems. Earth Sciences 24 pp 8795-

Egypt. J. Soil Sci. 57, No. 1 ( 2017 )
Kharche, V.K., Desai, V.N. and Pharande, A.L. (2011) Effect of sewage irrigation on soil properties, essential nutrient and pollutant element status of soils and plants in a vegetable growing area aroun Sci. 59 (2), 177184-

Khurana, M.P.S. and Singh, P. (2012) Waste Water Use in Crop Production: A R
Environment, 2 (4), 116131-

Klute, A. (1986) Methods of Soil Analysis, part $12^{\text {nd }} \mathrm{e}$ Am. Soc, Agron; Jnc.; soil Sci Soc Am. Maodiso

Ladwani K.D., Vivek, S.M. and Ramteke, D.S. (2012) Impact of Domestic Wastewater Irrigation on Soil Properties and Crop Yield. International Volume 2, Issue 10, ISSN 2250315-.

Magesan G.N., Mclay, C.D.A. and Lal, V.V. (1998) Nitrate leaching from a freely-draining volcanic sol/
irrigated with municipal sewage effluent in Zealand Agriculture,Ecosystems\& Environment 70,181187-.

McClean, C.J., Cresser, M.S., Smart, R.P., Aydinalp, C. and Karkat, A.V. (2003) Unsuitable irrigation practices in the Bursa plain, Turkey. In: Diffuse Pollution and Basin Management: M. Bruen, (Ed.) IWA Conference, It th Inional Whal Specialized August 1721-st, 2003, Dublin, Ireland, 2003. D, 60-

Mollahoseini, H. (2013) Long term effects of municipa wastewater irrigation on some properties of an. Intl. J. Agron. Plan Prod. 4 (5), 10231028-

Narwal, R.P., Gupta, A.P., Singh, A. and Karwasra, S.P.S. (1993) Composition of some city waste waters and their effect on of some city wase Annals of Biology, 9, 239245-

Page, A.L., Miller, R.H. and Keeney, D.R. (1982) Methods of Soil Analysis, part $22^{\text {nd }}$ ed. Am. Soc,

Pescod, M.D. (1992) Wastewater treatment and use in agriculture. FOA Irrigation and drainage Paper United Nation, Rome, Italy, $125 \mathrm{pp}$.

Rana, L., Dhankhar, R. and Chhikara, S. (2010) Soil characteristics affected by long term applicatio of sewage wastewater, International Journal
Roshdy, Nadia, M.K. (2009) Distribution and forms of some heavy metals in a contaninated soll at Assuit h.D Ph.D Thesis, Fac. of Agric., Assiut, Univ, Egypt.

Saffari, V.R. and Saffari, M. (2013) Effect of reated mu. and copper Arab J Geosci 6, 4475-4485.

Salem, M.M., El-Amir, S. Abdel-Aziz,S.M., Kandil ,M.F. and Mansour, S.F. (2000) Effect of irrigation whe sewage water on some chemical characteristics

Siebe, C. (1998) Nutrient inputs to soils and their uptake by alfalfa through long-term irrigation with Management, CAB International Oxford,. p. 119122.

USDA, (United States, Department of Agriculture) (1996) Soil Survey Investigations. Soil Survey

Weggler-Beaton, K., McLaughlin, M.J. and
Graham, R.D. (2000) Salinity increases cadmium Graham, R.D. (2000) Salinity increases cadmile with biosolids. Aust. J. Soil Res., 38 , 3745-.

Yao H., Zhang, Sh., Xue, X., Yang,J., hu, K. and y, $\mathbf{X} .(2013)$ Influence of the sewage irrigatio China. Front Environ. Sci. Eng 7(2), 273-280.

Yerasi, P.K.R., Reddy, Y. K., Reddy, G. and Prasad, D.M.R. (2013) Sewage irrigation can sustain the soll health. A review . Mnernational Journal of Agricultural Sciences, 3 (4), pp. 470472 -. Available
online at www internationalscholar-sjournals, org. 


\section{"التاثير طويل الامد لمياه الصرف الصحى المعالجة على بعض الخواص والحالة الغذائية للتربة

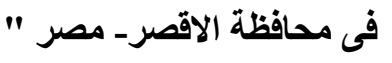 \\ رشنى مبارك فراج1 محمد علي الاسوقي2 ، أبو بكر عبد المنعم أبوبكر باشا1 و ناديه محمد كمال

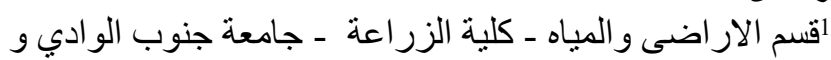

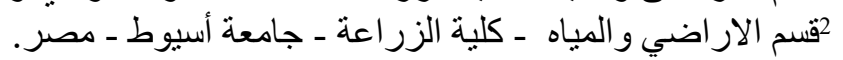

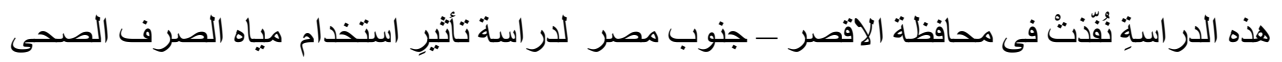

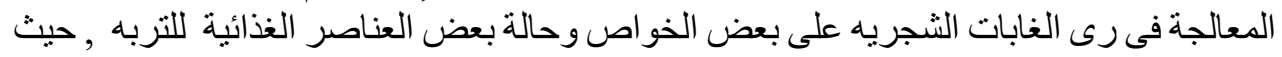

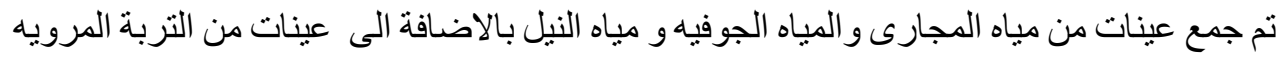
بهذه المياه , وتم تحليل هذه العينات و اسفرت نتائج التحليل على الاتى :-

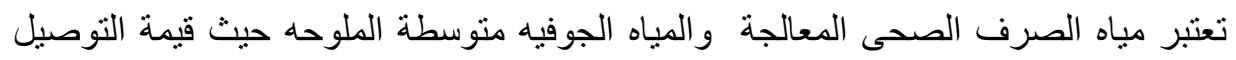

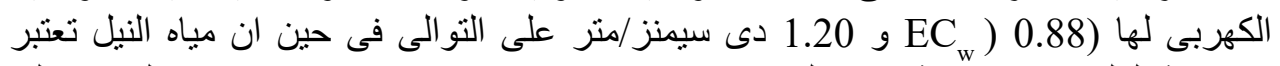

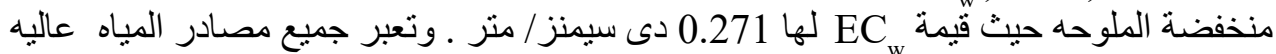

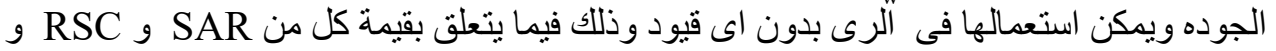

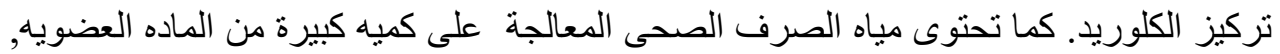
النيتروجين , الفوسفور و والبوتاسيوم مقارنة بالمياه الجوفيه ومياه النيل.

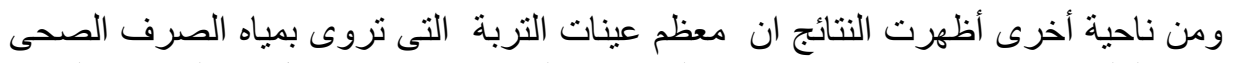

منخفضة الملوحة (13) (EC)

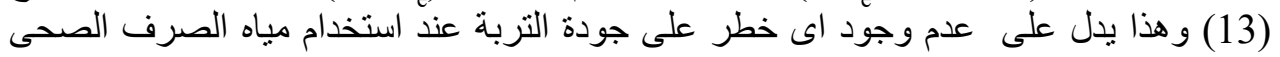

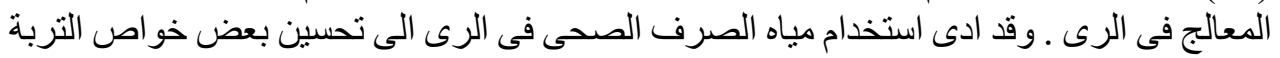

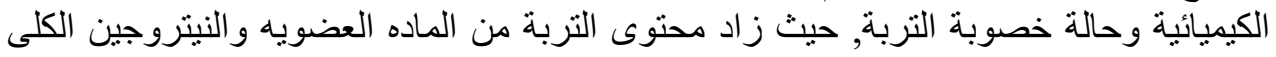

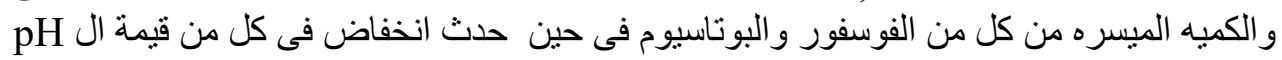

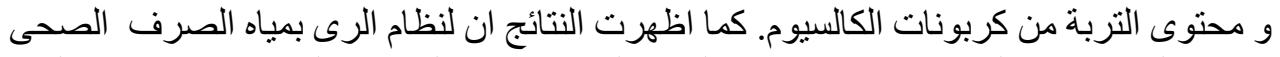

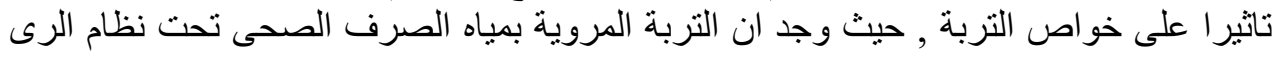

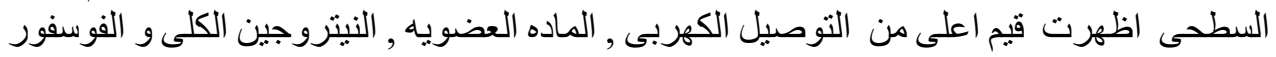

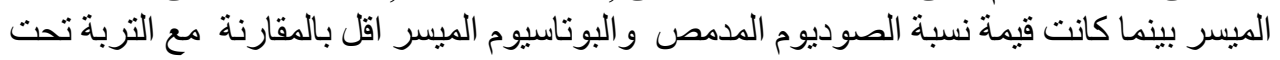

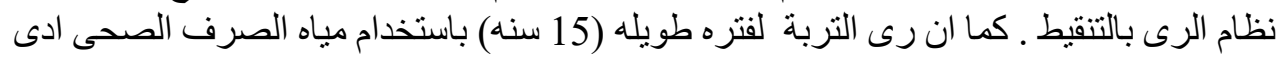

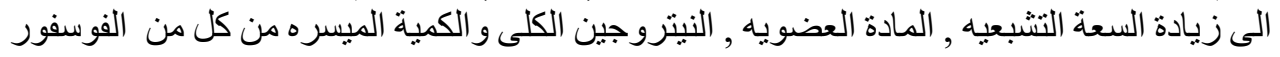

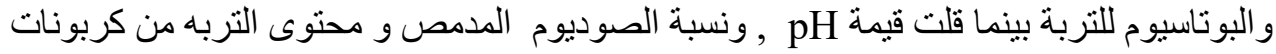

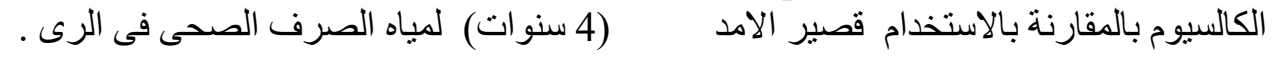

